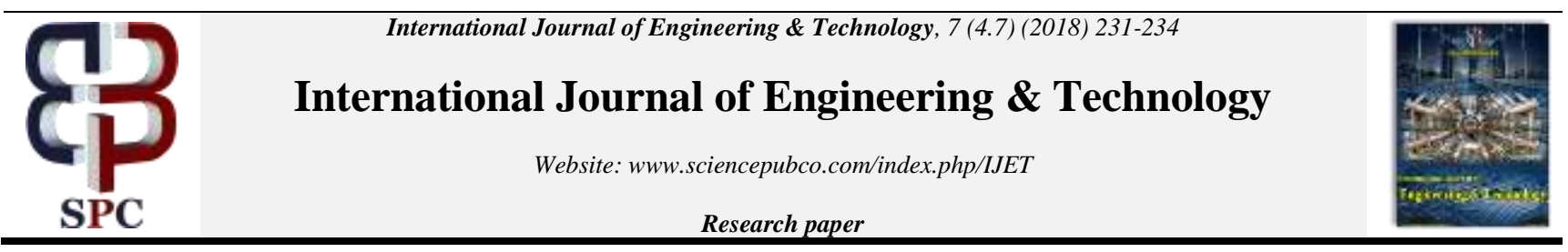

\title{
Investigating the Pollution of the Atmosphere by Motor Transport
}

\author{
Farid D. Yambyshev, Renat M. Shigabutdinov \\ Kazan Federal University \\ *Corresponding author E-mail: rosa_safina@mail.ru \\ Tel.: +79172495058
}

\begin{abstract}
Environmental pollution is one of the most serious global problems of mankind. Its impact on the public health becomes more acute every year. Ecotoxicants - harmful chemicals that pollute the environment - pose a great danger to humans and animals. Their sources are not only production and energy enterprises, but also motor transport. With the increase in the car fleet, the level of harmful impact on the environment is intensively increasing. For example, if at the beginning of the 1970s, hygienists determined the proportion of pollutants introduced into the atmosphere by road transport on average at $13 \%$, now this level has reached $50 \%$ and continues to grow.

This paper is devoted to the study of the extent of atmospheric pollution by road transport. Literature sources on this problem have been analyzed and summarized, specific types of pollutants released by the exploited vehicles and the results of their harmful effects on the environment and living organisms have been described. The authors of the paper obtained quantitative data on the average daily and average annual volumes of pollutants emitted into the atmosphere during the operation of vehicles in the city of Kazan.
\end{abstract}

Keywords: environment, motor transport, pollution, ecology, exhaust gases.

\section{Introduction}

Compound elements of harmful emissions of motor transport are involved in the processes of interaction with air components, resulting in the emergence of new harmful substances (secondary atmospheric pollutants). Pollutants enter into physical, chemical and photochemical interactions with the components of atmospheric air: 1) non-toxic substances: nitrogen, oxygen, hydrogen, water vapor and carbon dioxide, the content of which in the atmosphere under normal conditions does not reach the level harmful to humans; 2) carbon monoxide 3 ) nitrogen oxides ( 98\% NO, $\sim 2 \% \mathrm{NO}_{2}$ ), which, as they are in the atmosphere, combine with oxygen; 4) hydrocarbons (alkanes, alkenes, alkadienes, cyclones, aromatic compounds); 5) aldehydes, 6) carbon black, 7) lead compounds, and 8) sulfuric anhydride.

The sensitivity of the population to the action of the listed air pollutants depends on multiple factors, including age, sex, general health, nutrition, temperature and humidity, etc. Elderly people, children, patients, smokers, suffering from chronic bronchitis, coronary insufficiency, asthma, are more vulnerable. The result of the body's reaction to the effects of pollutants is the increase in mortality, morbidity, accumulation of contamination in organs and tissues [1].

\section{Methods}

The task is to determine the extent of atmospheric pollution by motor transport in the city of Kazan. The analysis is based on the calculation method. The object of research is a petrol station. Model of the vehicle in the motor including the torque converter, controller and valves is modeled in figure 1 as follows:

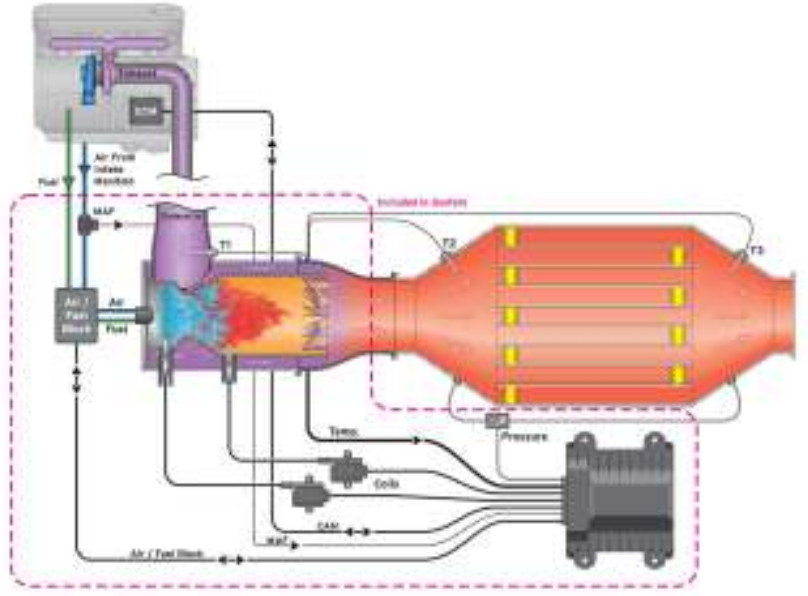

Fig. 1:. The model of motor

\section{Results and Discussion}

The share of motor vehicles in the total amount of environmental pollution in the cities and industrial centers reaches $70 \%$, which causes a serious environmental problem that accompanies the urbanization process [2]. Table 1 presents the composition of pollutants generated from the operation of automobile engines.

Table 1:. Composition of exhaust gases of automobile engines

\begin{tabular}{|l|l|l|l|}
\hline \multirow{2}{*}{ Components } & \multirow{2}{*}{ Dimension } & Limits of component concentrations \\
\cline { 3 - 4 } & & Petrol & Diesel \\
\hline Azote, $\mathrm{N}$ & \% of volume & $74 \ldots 77$ & $76 \ldots 78$ \\
\hline
\end{tabular}




\begin{tabular}{|c|c|c|c|}
\hline Oxygen, $\mathrm{O} 2$ & & $0,2 \ldots 8,0$ & $2 \ldots 18$ \\
\hline Water vapor, $\mathrm{H} 2 \mathrm{O}$ & & $3,0 \ldots 13,5$ & $0,5 \ldots 10,0$ \\
\hline $\begin{array}{l}\text { Dioxide of carbon, } \\
\mathrm{CO} 2\end{array}$ & & $5,0 \ldots 12,0$ & $1 \ldots 12,0$ \\
\hline $\begin{array}{l}\text { Hydrocarbons, } \mathrm{CH} \\
\text { (total) }\end{array}$ & & $0,2 \ldots 3,0$ & $0,01 \ldots 0,50$ \\
\hline $\begin{array}{l}\text { Carbon monoxide, } \\
\text { CO }\end{array}$ & & $0,1 \ldots 10,0$ & $0,01 \ldots 0,30$ \\
\hline Nitric oxide, NOx & & $0,0 \ldots 0,6$ & $0,005 \ldots 0,200$ \\
\hline Aldehydes & & $0,0 \ldots 0,2$ & $0,0 \ldots 0,06$ \\
\hline $\begin{array}{l}\text { Sulfur oxides } \\
\text { (sum) }\end{array}$ & \multirow{4}{*}{$\mathrm{mg} / \mathrm{m} 3$} & $0,0 \ldots 0,003$ & $0,0 \ldots 0,015$ \\
\hline Carbon black & & $0,0 \ldots 100$ & $0,0 \ldots 20000$ \\
\hline Benzapyrene & & $0,0 \ldots 25$ & $0,0 \ldots 10,0$ \\
\hline Lead compounds & & $0,0 \ldots 60$ & - \\
\hline
\end{tabular}

There are three main sources of toxic substances in cars: exhaust gases, crankcase gases and fuel fumes. The greatest share of chemical pollution of the environment is accounted for by exhaust gases. Complete combustion of fuel in internal combustion engines generates carbon dioxide and water vapor. The oxidation reactions are:

$\mathrm{C}+\mathrm{O}_{2}=\mathrm{CO}_{2}$

$2 \mathrm{H}_{2}+\mathrm{O}_{2}=2 \mathrm{H}_{2} \mathrm{O}$

Practically the composition of exhaust gases in the engine cylinders is very complex and consists of more than 200 components, a significant part of which is toxic [3]. The composition of harmful substances in the exhaust gases of diesel and gasoline car engines is shown in Fig. 1 and 2.

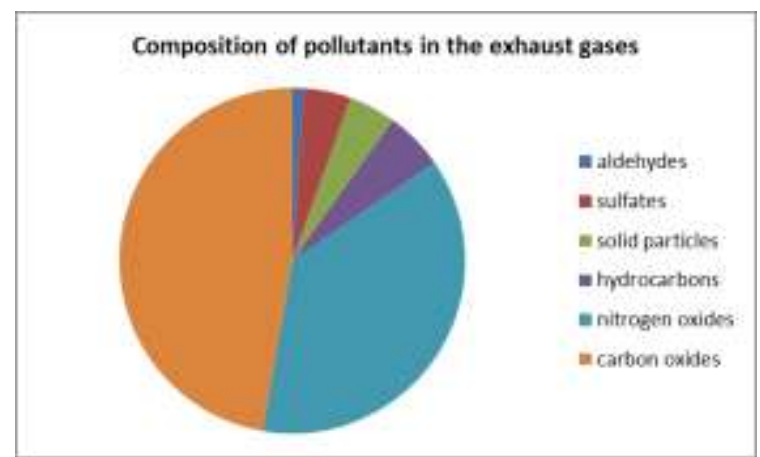

Fig. 2:. Composition of pollutants in the exhaust gases of diesel engines of cars



Fig. 3:. Composition of pollutants in the exhaust gases of gasoline engines of cars

Table 1 and Fig. 2, 3 show that the composition of exhaust gases differs significantly, primarily in the concentration of products of incomplete combustion - carbon monoxide, hydrocarbons, nitrogen oxides and soot. Toxic components of exhaust gases are: carbon monoxide, hydrocarbons, nitrogen oxides, sulfur oxides, aldehydes, soot, benzapyrene, lead compounds.
Toxic components of exhaust gases and evaporation from the fuel system adversely affect the human body. The severity of influence depends on their concentration in the atmosphere, the state of a person and his/her individual characteristics.

\subsection{Hydrocarbon Compounds}

Hydrocarbons are numerous compounds of various types (for example, $\mathrm{C}_{6} \mathrm{H}_{6}$ or $\mathrm{C}_{8} \mathrm{H}_{18}$ ) that consist of the initial or decomposed molecules of fuel. Their content increases not only when enriching, but also when the mixture is depleted, which is due to the increased amount of unburned fuel caused by excess air and misfiring in individual cylinders [4].

The most studied is the multi-nuclear aromatic hydrocarbon benzapyrene - carcinogenic substance. Getting through the respiratory tract into the lungs, it stays in the body.

Components of harmful emissions with increased reactivity interact with each other and components of the atmospheric air, resulting in physical, chemical and photochemical interactions. The reactions of synthesis and decomposition, oxidation and reduction are carried out between the gaseous components of the pollutants and atmospheric air.

Hydrocarbons in the atmosphere undergo various transformations (oxidation, polymerization), interacting with other atmospheric pollution, primarily under the influence of solar radiation. As a result of these transformations, peroxides, free radicals, compounds with oxides of nitrogen and sulfur are formed.

Emissions propagate in the atmosphere according to certain regularities. Solid particles larger than $0.1 \mathrm{~mm}$ settle on the surfaces because of the action of gravitational forces. Particles that are less than $0.1 \mathrm{~mm}$ in size, as well as gas impurities, propagate in the atmosphere under the influence of diffusion processes. They enter into physico-chemical interactions between themselves and with the components of the atmosphere, and their effect is manifested in local areas within certain regions [5]

\subsection{Carbon Monoxide}

Carbon monoxide (CO), entering the human body with inhaled air, displaces oxygen from the blood. This is explained by the fact that the absorbance of $\mathrm{CO}$ with blood is 240 times higher than that of oxygen. Direct influence is exerted by CO on tissue biochemical processes, leading to a violation of fat and carbohydrate metabolism, vitamin balance, etc. As a result of oxygen starvation, attention is weakened, reaction is slowed down, and work capacity decreases. A higher concentration of $\mathrm{CO}(0.02 \ldots 0.033 \%)$ leads to the development of atherosclerosis, myocardial infarction and chronic lung diseases [6].

Carbon monoxide diffuses rapidly in the atmosphere. It is intensively absorbed by soil microorganisms; in the atmosphere, it can be oxidized to $\mathrm{CO}_{2}$ in the presence of impurities - strong oxidants, peroxide compounds and free radicals [7].

Carbon dioxide $\mathrm{CO}_{2}$ does not have a toxic effect on the human organism, is well absorbed by plants with the release of oxygen. But its presence in the earth's atmosphere in a large amount absorbing the sun rays, creates a greenhouse effect, leading to the socalled "thermal pollution". As a consequence, various climatic anomalies are observed.

Among the secondary pollutants are acids, formed as a result of the reaction of acidic oxides with water. The harmful effects of acid rain show up in the destruction of vegetation and the acceleration of corrosion of metal structures.

\subsection{Nitric Oxide}

Nitrogen oxides $\mathrm{NO}_{\mathrm{x}}$ represent a set of the following compounds: $\mathrm{N}_{2} \mathrm{O}, \mathrm{NO}, \mathrm{N}_{2} \mathrm{O}_{3}, \mathrm{NO}_{2}, \mathrm{~N}_{2} \mathrm{O}_{4}$ and $\mathrm{N}_{2} \mathrm{O}_{5}$. NO prevails in the exhaust gases of automobile engines (99\% in gasoline engines and more than $90 \%$ in diesel engines) [8]. 
Nitrogen oxides are involved in processes leading to the formation of smog. They irritatingly act on the mucous membranes of the eyes, nose and mouth. The danger of their impact is also in not immediate, but gradual poisoning of organisms, and there are no neutralizing agents.

Emitted into the atmosphere, nitrogen monoxide under the influence of sunlight is intensely oxidized by atmospheric oxygen to nitrogen dioxide. The kinetics of further conversions of nitrogen dioxide is determined by its ability to absorb ultraviolet rays and dissociate into nitrogen monoxide and atomic oxygen in photochemical smog processes.

\subsection{Sulfur Oxides}

Sulfur oxides are formed by the combustion of sulfur contained in the fuel.

$\mathrm{S}+\mathrm{O}_{2}=\mathrm{SO}_{2}$

$2 \mathrm{SO}_{2}+\mathrm{O}_{2}=2 \mathrm{SO}_{3}$

Sulphurous anhydride $\mathrm{SO}_{2}$ is a colorless gas with a sharp odor. Its detrimental effect on the upper respiratory tract is explained by the absorption of $\mathrm{SO}_{2}$ by the moist surface of the mucous membranes and the formation of acids in them. It disrupts protein metabolism and enzymatic processes, causes eye damage, coughing.

In a free atmosphere, the sulfur dioxide gas after a while is oxidized to sulfuric anhydride or reacts with other compounds, in particular hydrocarbons. The oxidation of sulfurous anhydride to sulfuric acid occurs in the free atmosphere during photochemical and catalytic reactions. In both cases, the final product is an aerosol or a solution of sulfuric acid in rainwater [9].

Hydrogen sulfide and carbon disulfide when reacted with other pollutants undergo a slow oxidation to sulfuric anhydride in the free atmosphere. Sulphurous anhydride can be adsorbed on the surface of solid particles from metal oxides, hydroxides or carbonates and oxidize to sulphate.

In addition to the exhaust gases, the sources of environmental pollution include crankcase gases. They are formed in the crankcase of the gasoline engine [10].

\subsection{Solid Particles}

Soot, metal oxides, silicon dioxide, sulphates, nitrates, asphalts, lead compounds and organic solvent-soluble resins, phenols, aldehydes, varnish, carbon, heavy fractions contained in fuel and oil substances.

Soot is formed during the thermal expansion of hydrocarbons in the gas or vapor phase with a lack of oxygen. Emissions of soot from diesel engines are greater than for engines with spark ignition and depends on the quality of fuel [11].

Soot when ingested into the human body causes negative consequences in the respiratory organs. Relatively large particles of carbon black of $2 \ldots 10 \mu \mathrm{m}$ are easily excreted from the body, while small particles of $0.5 \ldots 2 \mu \mathrm{m}$ are retained in the lungs, respiratory tract, and cause allergies. Like any aerosol, soot pollutes the air, worsens visibility on the roads, absorbs heavy aromatic hydrocarbons, including benzopyrene, on its srface. The composition of solid particles, in addition to soot, includes sulfur compounds, lead.

The main compounds of lead in the exhaust gases of cars are chlorides and bromides, as well as oxides, sulfates, fluorides, phosphates and some of their intermediates. About 50\% of the lead remains in the form of carbon deposits on engine parts and in the exhaust pipe, the excess escapes into the atmosphere with the exhaust gases [12]. Table 2 shows the average daily values of the maximum permissible concentration (MPC) for some toxic substances [13].

Table 2:. Maximum permissible concentration of toxic substances

\begin{tabular}{|l|l|l|}
\hline \multicolumn{2}{|l|}{ Substance } & Content $\mathbf{~ m g} / \mathbf{~ m 3}$ \\
\hline \multirow{2}{*}{ Oxides nitrogen } & NO & 0.06 \\
\cline { 2 - 3 } & NOx & 0.1 \\
\hline
\end{tabular}

\begin{tabular}{|l|l|l|}
\hline \multirow{2}{*}{ Lead compounds } & $\mathrm{Pb}$ & 0.0003 \\
\cline { 2 - 3 } & $\mathrm{Pb}(\mathrm{NO} 3) 2$ & 0.0003 \\
\hline Sulfur oxide & $\mathrm{SO} 2$ & 0.2 \\
\hline Carbon monoxide & $\mathrm{CO}$ & 3 \\
\hline Carbon (black) & $\mathrm{C} 1$ & 0.05 \\
\hline Benzapyrene & $\mathrm{C} 20 \mathrm{H} 12$ & 0,000001 \\
\hline Gasoline & $\mathrm{C} 1$ & 1.5
\end{tabular}

A car with an average annual mileage of 15 thousand $\mathrm{km}$ "breathes" 4.35 tons of oxygen and "exhales" 3.25 tons of carbon dioxide, 0.8 tons of carbon monoxide, 0.2 tons of hydrocarbons, 0.04 tons of nitrogen oxides. These are emissions that dissipate practically throughout the entire territory of cities, and directly in the surface layer of the atmosphere.

Table 3 shows the share of motor transport in general atmospheric pollution in the largest cities in the world [13].

Table 3:. The share of road transport in total atmospheric pollution in the world's largest cities, $\%$.

\begin{tabular}{|l|l|l|l|}
\hline City & Carbon Oxide & Hydrocarbons & Nitrogen oxides \\
\hline Madrid & 95 & 90 & 35 \\
\hline Stockholm & 99 & 93 & 53 \\
\hline Tokyo & 95 & 95 & 33 \\
\hline Toronto & 98 & 69 & 19 \\
\hline Los Angeles & 98 & 66 & 72 \\
\hline New York & 97 & 63 & 31 \\
\hline Moscow & 96 & 65 & 33 \\
\hline Saint-Petersburg & 88 & 79 & 32 \\
\hline
\end{tabular}

According to official statistics, the population of Kazan in 2018 is 1243,500 people. The total number of cars is 395,360 units. For about 320 cars account for 1000 people.

About 600 cars on average pass through one petrol station daily. 180 cars $(30 \%)$ of them are freight cars and $420(70 \%)$ are passenger cars. It is known that the average car emits in a year:

$135 \mathrm{~kg}$ of carbon monoxide,

$25 \mathrm{~kg}$ of nitrogen oxides,

$20 \mathrm{~kg}$ of hydrocarbons,

7 to 10 kilograms of benzapyrene,

$4 \mathrm{~kg}$ of sulfur dioxide,

$1.2 \mathrm{~kg}$ of solid particles

Based on these data, in the city of Kazan the car emits the following amount of harmful substances per one day of operation (the calculation is made for one petrol station in Kazan):

$\mathrm{CO}-90 \mathrm{~kg}$ (freight cars) and $95 \mathrm{~kg}$ (passenger cars);

$\mathrm{NO}_{2}-13 \mathrm{~kg}$ (freight cars) and $19 \mathrm{~kg}$ (passenger cars);

$\mathrm{S}$ (soot) - $35 \mathrm{~kg}$ (freight);

$\mathrm{SO}_{2}-900 \mathrm{~g}$ (freight);

$\mathrm{Pb}-0.036 \mathrm{~g}$ (freight) and $0.1134 \mathrm{~g}$ (passenger cars).

Total emissions of freight and passenger cars into the environment per one day in Kazan are shown in Fig. 4 (Calculations for 1 petrol station):

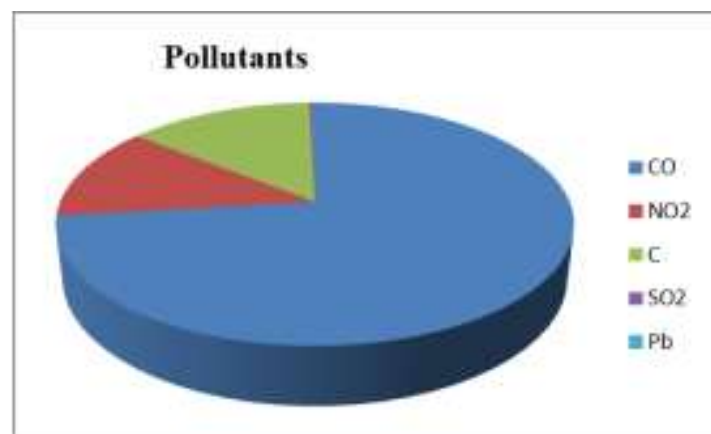

Fig. 4:. Emissions of pollutants at one point of filling stations in the city of Kazan

There are 185 registered petrol stations in Kazan. The data obtained on the basis of our calculations on the amount of pollutants 
emitted into the atmosphere at all petrol stations for one day are given in Table 4 and Fig. 5.

Table 4:. Total emissions of pollutants at all filling stations in the city of Kazan.

\begin{tabular}{|l|l|}
\hline $\mathrm{CO}$ & $34225 \mathrm{~kg}$ \\
\hline $\mathrm{NO} 2$ & $5920 \mathrm{~kg}$ \\
\hline $\mathrm{C}$ (carbon black) & $6475 \mathrm{~kg}$ \\
\hline $\mathrm{SO} 2$ & $166,5 \mathrm{~kg}$ \\
\hline $\mathrm{Pb}$ & $36,0565 \mathrm{~kg}$ \\
\hline
\end{tabular}

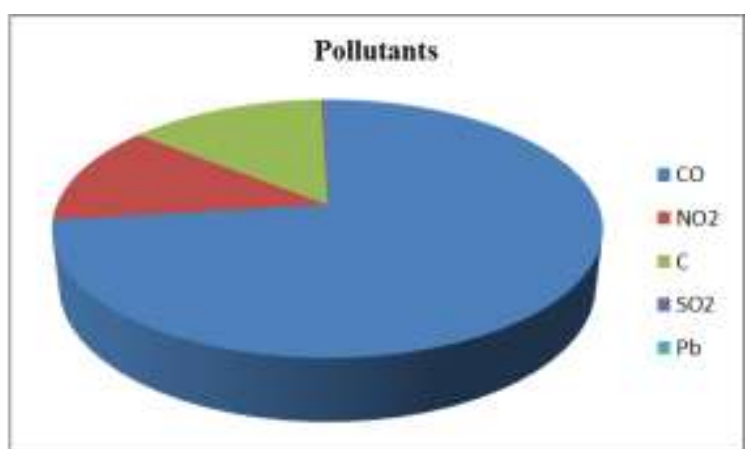

Fig. 5:. Emissions of pollutants at all filling stations in the city of Kazan

Some European countries have made efforts to gradually shift the entire car fleet to electric vehicles in order to preserve the environment and health. In particular, in Norway, a car with electric motors - electric vehicles and rechargeable hybrids - equaled sales with cars running gasoline and diesel fuel. The government aims to make the purchase of conventional cars uneconomical for consumers by 2025 , thus bringing the share of sales of new cars with electric motors to $100 \%$. Owners of cars that do not emit harmful substances into the atmosphere get significant advantages: they do not pay fees on highways, use ferries free of charge and can park in municipal parking, use dedicated lanes for public transport. While owners of petrol cars, on the contrary, experience serious inconveniences, in particular, prohibitions for entering the centers of large cities of the country.

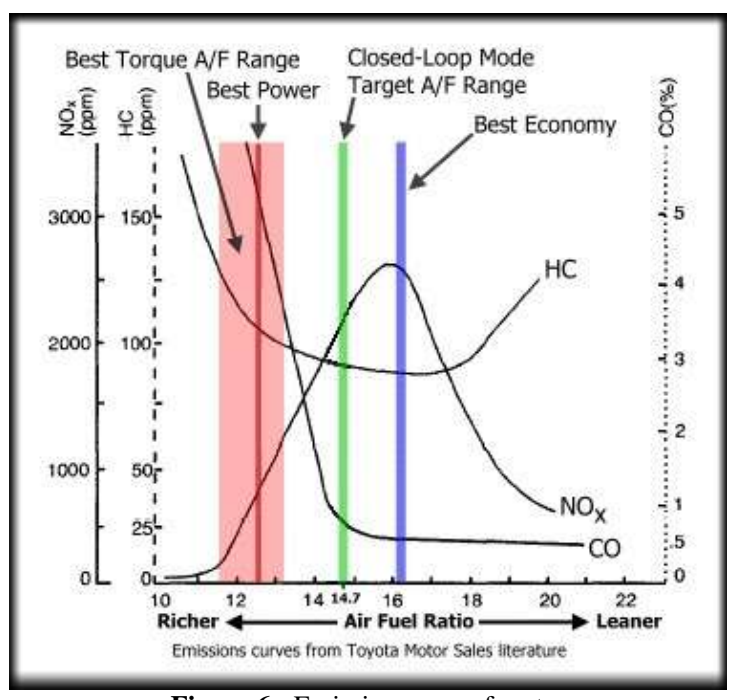

Figure 6:. Emissions map of motor

\section{Summary}

Currently, the world's leading manufacturers have created numerous models of cars producing no harmful emissions into the environment, which are actively introduced into operation. Governments of developed countries strongly support such developments in order to preserve nature for future generations. In Russia, this trend is still weak, but further development of motor transport in the country requires a radical review of the industry's strategy for setting up a mass production of eco vehicles.

\section{Conclusions}

To reduce the negative impact of transport on the environment and on human health in our country, it is necessary to reduce the energy intensity of transport to the level of indicators of advanced countries, as well as motivate the transfer of vehicle owners to purchase cars that use environmentally friendly (alternative) energy. In the context of rapid growth in the number of cars and the intensity of road traffic, it is also necessary to develop a network of highways, in particular, the construction of road detours around large cities and the reconstruction of busy sections, equipping roads with modern engineering means of protection of adjacent territories from noise and pollution, the construction, repair and maintenance of highways.

The transport strategy of the Russian Federation for the period until 2030 involves the implementation of such measures as the increase in the fleet of fuel-efficient vehicles with low fuel consumption; strengthening of control over the technical condition of the operated cars on environmental indicators; limiting of emissions of climatic gases and waste disposal of transport enterprises; transition to global environmental standards for consumed fuels; transfer of $50 \%$ of automobile fleets of large cities to alternative fuels.

\section{Acknowledgement}

The work is performed according to the Russian Government Program of Competitive Growth of Kazan Federal University.

\section{References}

[1] Krzyzanowski M. Health Effects of Transport-Related Air Pollution: Summary for Policy-Makers/M. Krzyzanowski. - Copenhagen: World Health Organization, Regional Office for Europe, 2005. - 12 p. 12 URL: http://www.euro.who.int/_data/assets/pdf_file/0007/74716/e86650 sum.pdf?ua $=1$

[2] [1] Stepanova N.V. Impact assessment and risk of pollution of atmospheric air by motor transport emissions to human health /N.V. Stepanova, N.V. Sviatova, I.Kh. Sabirova, A.V. Kosov // Fundamental research. -2014. -No. 10-6. - p. 1185-1190.

[3] Sozinova T.V. Methods for reducing the environmental impact of vehicles /T.V. Sozinova, E.V. Nosova, T.N. Shishelova, A.V. Nosov // Fundamental research. -2005. -No.1.- p. 56-57.

[4] https://studwood.ru/1177887/ekologiya/zagryaznenie_atmosfery_av totransportom

[5] Lykova A. S. Zagryaznenie vozduha gorodskih ulits okisiyu ugleroda i ee vrednoe vliyanie. Kand. diss. [Air pollution of city streets carbon monoxide and its adverse effect. Cand. Diss.]. Leningrad, $1953,16 \mathrm{p}$.

[6] Gukhman G. Impact of a transport complex on environment. Energiya [Energy], 1999, 1 1, pp. 42-45. [in Russian]

[7] Ewing R., Walters J. Measuring the benefits of compact development on vehicle miles and climate change. Environmental Practice. 2009, 11 (3), pp. 196-208.

[8] http://ustroistvo-avtomobilya.ru/sistemy-snizheniyatoksichnosti/zagryaznenie-avtotransportom-okruzhayushhej-sredy/

[9] Aksenov I.Ia., Aksenov V.I. Transport and environmental protection. - M.: Transport, 1986. - p. 176.

[10] http://urban.plandex.ru/avtotransport-kak-osnovnoj-istochnikzagryaznenij

[11] Morozov K.A. Toxicity of automobile engines: - M.: LegionAvtodata, 2001. - p. 80

[12] Litvinova N.A. Motor transport and the ecology of the urban air environment: monograph / N.A. Litvinova. - Tyumen: RIO FGBOU HPE "TyumGASU", 2016. - p. 170.

[13] http://doc.mpedagog.ru/zagryaznenie-avtotransportomokruzhayushej-sredi.html 